\title{
Identification of New Diterpenes as Putative Marker Compounds Distinguishing Agnus Castus Fruit (Chaste Tree) from Shrub Chaste Tree Fruit (Viticis Fructus)
}

Authors

Affiliations
Naohiro Oshima ${ }^{1 *}$, Sayaka Masada ${ }^{1 *}$, Ryuta Suzuki ${ }^{1}$, Kanae Yagi $^{1}$, Hiroshi Matsufuji ${ }^{2}$, Emi Suenaga ${ }^{1}$, Yutaka Takahashi ${ }^{3}$, Tadahiro Yahagi ${ }^{4}$, Masato Watanabe ${ }^{5}$, Shoji Yahara ${ }^{5}$, Osamu lida ${ }^{6}$, Nobuo Kawahara ${ }^{6}$, Takuro Maruyama ${ }^{1}$, Yukihiro Goda ${ }^{1}$, Takashi Hakamatsuka ${ }^{1}$

The affiliations are listed at the end of the article
Key words

- Vitex agnus-castus

- Vitex rotundifolia

- Vitex trifolia

- Verbenaceae

- Lamiaceae

- Agnus Castus Fruit (ACF)

- Shrub Chaste Tree Fruit (SCTF)

- chastol

- marker compound received February 6, 2015 revised July 11,2015

accepted August 10, 2015

\section{Bibliography}

DOI http://dx.doi.org/ 10.1055/s-0035-1558089

Planta Med 2016; 82: 147-153

(c) Georg Thieme Verlag KG

Stuttgart · New York .

ISSN 0032-0943

\section{Correspondence}

\section{Dr. Takashi Hakamatsuka}

Phytochemistry and Narcotics National Institute of Health

Sciences

Division of Pharmacogonosy

1-18-1 Kamiyoga, Setagaya-ku

Tokyo 158-8501

Japan

Phone: + 81337009159

Fax: +81337009159

thakama@nihs.go.jp

\section{Abstract}

$\nabla$

Agnus Castus Fruit is defined in the European Pharmacopoeia as the dried ripe fruit of Vitex agnus-castus. In Europe it is used as a medicine targeting premenstrual syndrome and climacteric disorder. In Japan, Agnus Castus Fruit is becoming popular as a raw material for over-the-counter drugs and health food products, though its congenic species, Vitex rotundifolia and Vitex trifolia, have been used as Shrub Chaste Tree Fruit in traditional medicines. Therefore, it is important to discriminate these Vitex plants from the viewpoint of regulatory science. Here we tried to identify putative marker compounds that distinguish between Agnus Castus Fruit and Shrub Chaste Tree Fruit. We analyzed extracts of each crude drug by liquid chromatography-mass spectrometry, and performed differential analysis by com-

\section{Introduction}

\section{$\nabla$}

Vitex agnus-castus L. (Lamiaceae) is a deciduous shrub, native to the entire Mediterranean region and western Asia. Its fruit has been used for more than 2500 years to treat a variety of gynecologic conditions [1]. Various flavonoids [2,3], iridoids [4] and diterpenes [5] have been reported as secondary metabolites in the fruit of $V$. agnus-castus. Among them, 6 $\beta, 7 \beta$-diacetoxy-13-hydroxy-labda-8,14-diene and rotundifuran have inhibitory effects on the dopamine- $\mathrm{D}_{2}$ receptor [6].

Today, the dried ripe fruit of $V$. agnus-castus is defined under the names Agnus Castus Fruit (ACF) and Chaste Tree, respectively, in the European Pharmacopoeia [7] and the United States Pharmacopeia [8]. ACF products are distributed as overthe-counter (OTC) drugs to treat premenstrual

\footnotetext{
${ }^{*}$ These authors contributed equally to this work.
}

parison of each chromatogram to find one or more peaks characteristic of Agnus Castus Fruit. A peak was isolated and identified as an equilibrium mixture of new compounds named chastol (1) and epichastol (1a). The planar structures of $\mathbf{1}$ and 1a were determined spectroscopically. Their relative configurations were revealed by nuclear Overhauser effect spectroscopy and differential nuclear Overhauser effect-NMR data. Since avoiding contamination from closely related species is needed for the quality control of natural pharmaceuticals, this information will be valuable to establish a method for the quality control of both, Agnus Castus Fruit and Shrub Chaste Tree Fruit products.

Supporting information available online at http://www.thieme-connect.de/products

syndromes (PMS) and climacteric disorders based on clinical evidence in Europe [9,10]. Although ACF has been generally distributed as a health food product in Japan, a direct OTC drug derived from ACF was recently approved by the Ministry of Health, Labour and Welfare. Western herbal medicine is currently one of the most attractive complementary medications that are useful for self-medication, and ACF extract is the second example of an active ingredient of a direct OTC drug derived from a Western medicinal herb available on the Japanese market; the first was an extract of the red leaves of Vitis vinifera L. (Vitaceae). On the other hand, congenetic plants native to East Asia, Vitex rotundifolia L., Vitex trifolia L., and Vitex negundo L. are used as sources of crude drugs in traditional Oriental medicine. The fruits of $V$. rotundifolia and $V$. trifolia are prescribed as Shrub Chaste Tree Fruit (SCTF) with the Latin name Viticis Fructus in the Japanese standards for non-pharmacopoeial crude drugs 2012 (Non- 
JPS 2012), and are used as components of some traditional Japanese medicines (Kampo formulations) due to their pain relief, sedative and anti-inflammatory effects. Thus, fruits of several Vitex plants are properly considered herbal medications. However, the macroscopic appearance of Vitex fruits is very similar for ACF and its congener species. In fact, the 8th edition of the European Pharmacopoeia (EP8.0) requires a purity test by macroscopic analysis based on the size of the fruit to discriminate $V$. agnuscastus from other Vitex species. Considering the internationalization of the supply chain of herbal plants, this situation could lead to misidentification of the botanical origin of the crude drugs, resulting in unexpected adverse reactions as well as in a decline in their pharmaceutical efficacy. Therefore, an appropriate discrimination method for the drugs derived from Vitex fruits is necessary.

According to the stipulation for ACF in EP8.0 it must pass a content test, requiring a casticin content $\geq 0.08 \%$ and an identification test confirming that both agnuside and aucubin are detectable by TLC. However, since these constituents have been isolated from SCTF [11-13], ACF products adulterated with SCTF could be overlooked under the current regulation. Therefore, for proper regulation, there is a pressing need to establish marker compounds for discriminating ACF from SCTF.

In the present study, we confirmed the source plants of commercially available ACF and SCTF by DNA sequence analysis. Subsequently, we analyzed extracts of the crude drugs by Orbitrap LC-MS to allow for an accurate mass analysis and a composition estimation, in order to identify possible characteristic compounds of ACF by comparing its chromatographic patterns in a differential analysis to SCTF. We isolated two novel diterpenes from ACF, which were not found in SCTF and elucidated their structures on the basis of spectroscopic data from NMR and MS.

\section{Results}

$\nabla$

The botanical sources of crude drug samples designated as ACF and SCTF were determined by querying the GenBank nucleotide sequence database using the nucleotide sequences of the matK and FLORICAULA/LEAFY (FLO/LFY) genes ( Table 1). Partial sequences of the matK gene from two ACF products, ACF-1 and 2, were identical to the sequence of $V$. agnus-castus (GenBank accession no. AB284182). Among the SCTF products, SCTF-1, 2 and 5 had sequences most similar to V. trifolia (AB284175), and SCTF3 and 4 had sequences similar to $V$. rotundifolia (AB284177). Since the nucleotide sequences of $V$. trifolia and $V$. rotundifolia are too similar to identify these species based on only a single
DNA region, the FLO/LFY region was also amplified to determine its sequence. The results based on the sequence of the FLO/LFY second intron agreed with a botanical origin of ACF- 1 and 2 being $V$. agnus-castus L., whereas the nucleotide sequences obtained from SCTF-2, 3, 4 and 5 were more similar to these of $V$. rotundifolia L. (LC012527) than to those of V. trifolia L. (LC012528), and the sequence of SCTF-1 was not conclusive by direct sequencing. By subcloning a short fragment of the FLO/LFY second intron from SCTF-1, we found that SCTF-1 contained both $V$. trifolia and $V$. rotundifolia. Considering also the observation that the sequence similarities of SCTF samples to congeners other than $V$. trifolia L. and V. rotundifolia L. were not very high, we confirmed the usage of samples of the correct origin for the SCTF products.

To discover candidate marker compounds for ACF, an automated differential analysis of the metabolic profiles of ACF and SCTF crude drug samples was performed using SIEVE software. After alignment and peak detection, 2253 peaks were obtained, and these peaks were filtered to 23 on the basis of a ratio $>10.0$ and a $\mathrm{p}$-value $<0.15$. Three of them were excluded from the candidates, because they had even mass numbers $(m / z 350,396$ and 520 for $[\mathrm{M}-\mathrm{H}]^{-}$) and each calculated formula was not acceptable for natural products. Visual confirmation of the candidate peaks on chromatograms in each extracted mass range led to omitting 13 peaks, because their actual intensities from SCTF samples were too large to recognize them as the specific peaks for ACF samples. We finally obtained 7 peaks as putative marker compounds for ACF and selected ID 1552 (RT $19.02 \mathrm{~min}, \mathrm{~m} / \mathrm{z}$ 335.2228, formula $\mathrm{C}_{20} \mathrm{H}_{31} \mathrm{O}_{4}$ for $[\mathrm{M}-\mathrm{H}]^{-}$) as the first target to identify the chemical structure. The total ion chromatograms of the ACF and SCTF samples, the extracted ion chromatograms of ACF and SCTF samples at the range of $m / z$ 335.22-335.23, the reconducted ion chromatogram of the Peak ID 1552 by SIEVE software, and the MS and MS/MS spectra of the Peak ID 1552 from ACF-2, are shown in 0 Fig. 1.

The ACF health food product was furnished as a source material of Peak ID 1552 and repeated column chromatography and preparative TLC of a $\mathrm{CHCl}_{3}$ extract of the ACF health food product afforded compound 1/1a as a mixture. Compound 1/1a was obtained as a white powder. The ${ }^{1} \mathrm{H}-\mathrm{NMR}$ and ${ }^{13} \mathrm{C}$-NMR spectroscopic data of $\mathbf{1} / \mathbf{1}$ a ( $\odot$ Tables $\mathbf{2}$ and $\mathbf{3}$ ) were very similar to those of known compounds leucasperols A and B [14], except for the chemical shift of the A-ring, especially at the $\mathrm{C}-3$ position. The ${ }^{13} \mathrm{C}$ chemical shifts of $\mathrm{C}-3$ of $1 / 1$ a were $\delta_{C} 41.5 / 41.5$, whereas those of leucasperols $A$ and $B$ were $\delta_{C} 78.2 / 78.4(\mathrm{~A} / \mathrm{B})$. In addition to the high-field shift of C-3, DEPT signals of $\delta_{C} 41.5 / 41.5$ indicated methylene groups. Moreover, the molecular formula of $\mathbf{1 /}$

Table 1 ACF and SCTF crude drugs used in this study and their botanical origin.

\begin{tabular}{|c|c|c|c|c|c|c|}
\hline \multirow[t]{2}{*}{ Sample ID } & \multirow[t]{2}{*}{ Product name } & \multirow[t]{2}{*}{ Distributor country } & \multirow[t]{2}{*}{ Lot Nos. } & \multicolumn{3}{|c|}{ DNA identification } \\
\hline & & & & matK region & $\begin{array}{l}\text { LFY direct } \\
\text { sequencing }(1.3 \mathrm{kp})\end{array}$ & $\begin{array}{l}\text { LFY subcloning } \\
\text { ( } 280 \mathrm{bp})\end{array}$ \\
\hline ACF-1 & Agni casti fructus Ph. Eur & Germany & 08015318 & V. agnus-castus & V. agnus-castus & not sequenced \\
\hline ACF-2 & Agni casti fructus tot. & Germany & B116424 & V. agnus-castus & V. agnus-castus & not sequenced \\
\hline SCTF-1 & Shrub Chaste Tree Fruit & Japan & 024011001 & V. trifolia & undetermined & $\begin{array}{l}\text { V. trifolia, } \\
\text { V. rotundifolia }\end{array}$ \\
\hline SCTF-2 & Shrub Chaste Tree Fruit & Japan & B2L0604 & V. trifolia & V. rotundifolia & not sequenced \\
\hline SCTF-3 & Shrub Chaste Tree Fruit & Japan & $6 B 22$ & V. rotundifolia & V. rotundifolia & not sequenced \\
\hline SCTF-4 & Shrub Chaste Tree Fruit & Japan & 024007001 & V. trifolia & V. rotundifolia & not sequenced \\
\hline SCTF-5 & Shrub Chaste Tree Fruit & Japan & 313016 & V. trifolia & V. rotundifolia & not sequenced \\
\hline
\end{tabular}




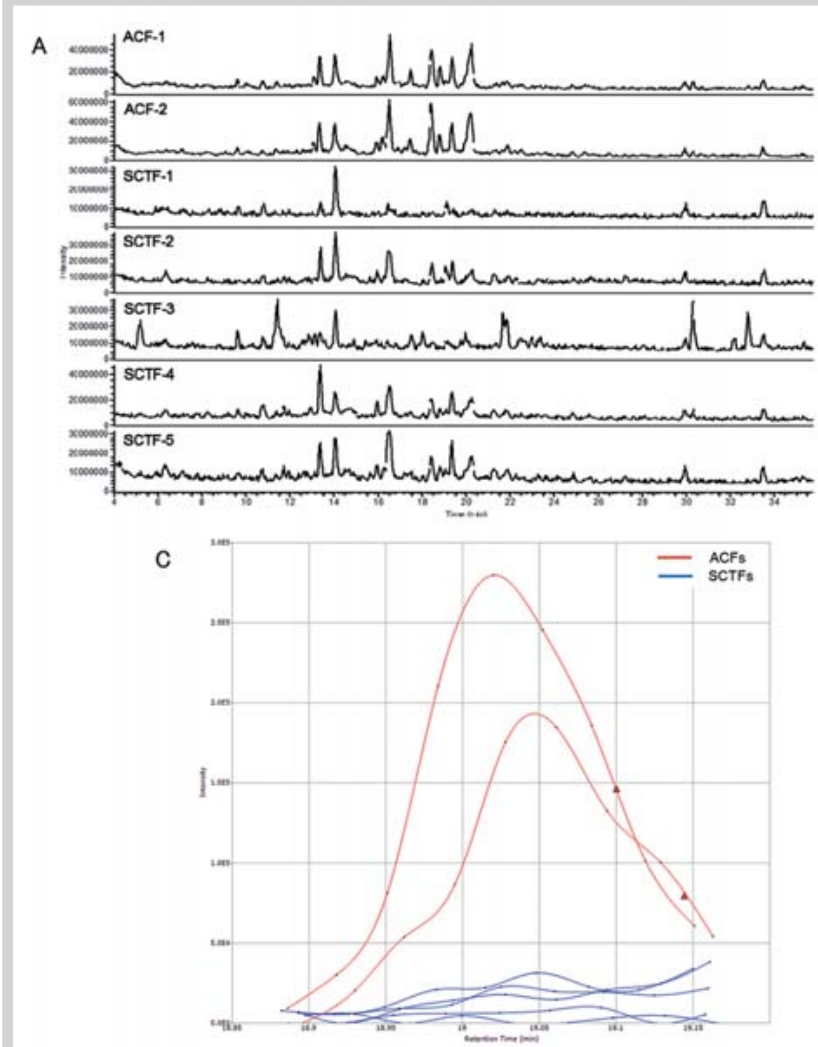

Fig. 1 A Total ion chromatograms of ACF and SCTF samples. B Extracted ion chromatograms of ACF and SCTF samples at $\mathrm{m} / \mathrm{z}$ 335.22-335.23. $\mathrm{C}$ Reconducted ion chromatogram of Peak ID 1552 by SIEVE software. D MS and
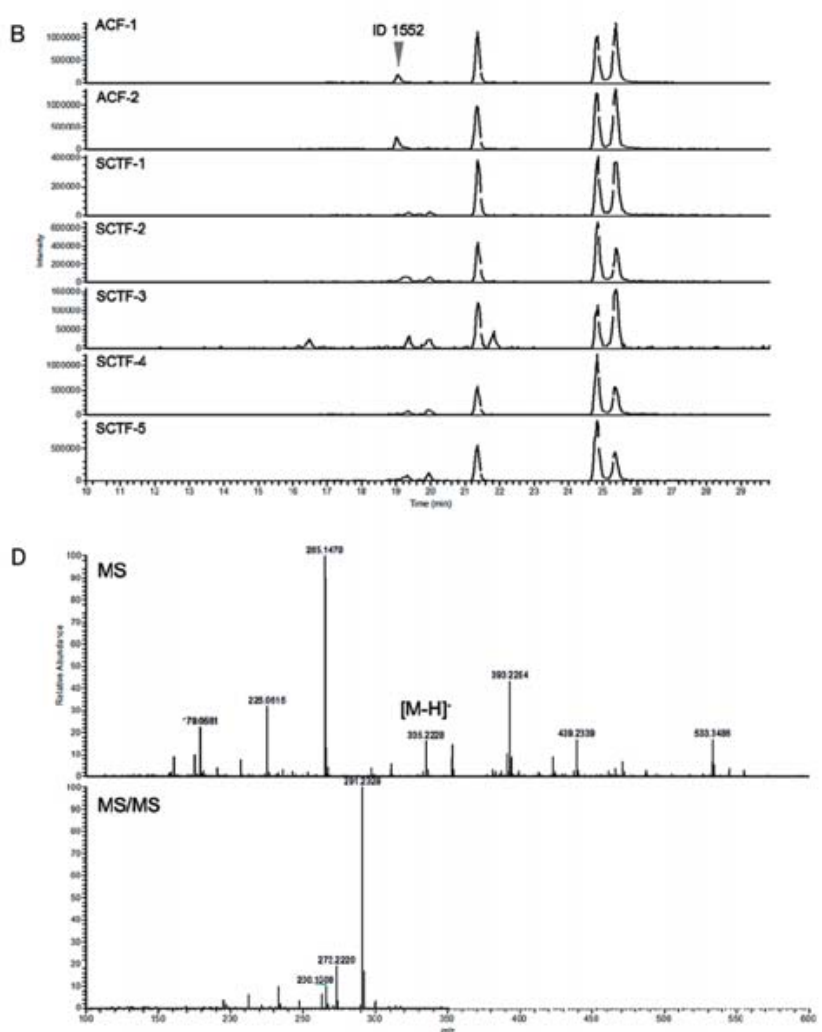

MS/MS spectra of Peak ID 1552 from ACF-2. (Color figure available online only.)

\begin{tabular}{|c|c|c|}
\hline \multirow[t]{2}{*}{ Position } & $\mathrm{a} / \mathrm{b}^{* 1}$ (5:2 mixture) & 1/1a (4:1 mixture) \\
\hline & $\delta_{\mathrm{H}}\left(\mathrm{CDCl}_{3}, \delta \mathrm{ppm}, J\right.$ in $\left.\mathrm{Hz}\right)$ & $\delta_{\mathrm{H}}\left(\mathrm{CDCl}_{3}, \delta \mathrm{ppm}, J\right.$ in $\left.\mathrm{Hz}\right)$ \\
\hline \multirow[t]{2}{*}{1} & $1.86(1 \mathrm{H}, \mathrm{m})$ & 1.56 (overlapping) \\
\hline & $1.44(1 \mathrm{H}, \mathrm{dt}, 12.5,3.7)$ & $1.41(1 \mathrm{H}, \mathrm{dd}, 10.4,4.8)$ \\
\hline \multirow[t]{2}{*}{2} & $1.64-1.68(1 \mathrm{H}, \mathrm{m})$ & 1.57 (overlapping) \\
\hline & $1.59(1 \mathrm{H}, \mathrm{dd}, 9.1,4.3)$ & $1.50(1 \mathrm{H}, \mathrm{m})$ \\
\hline \multirow[t]{2}{*}{3} & $3.11(1 \mathrm{H}, \mathrm{dd}, 11.6,4.3) / 3.07(1 \mathrm{H}, \mathrm{dd}, 11.3,4.3)$ & 1.20 (overlapping) \\
\hline & - & $0.97(1 \mathrm{H}$, ddd-like, $12.8,6.3,4.0)$ \\
\hline 5 & $2.63(1 \mathrm{H}, \mathrm{s}) / 2.64(1 \mathrm{H}, \mathrm{s})$ & $2.51(1 \mathrm{H}, \mathrm{s}) / 2.62(1 \mathrm{H}, \mathrm{s})$ \\
\hline \multirow[t]{2}{*}{7} & $2.41(1 \mathrm{H}, \mathrm{td}, 13.1,0.9) / 2.36(1 \mathrm{H}, \mathrm{td}, 13.1,1.0)$ & $2.43(1 \mathrm{H}, \mathrm{m})$ \\
\hline & $2.06(1 \mathrm{H}, \mathrm{dd}, 13.1,4.3) / 2.01$ (1H, overlapping) & $2.00(1 \mathrm{Htd}, 12.8,4.8)$ \\
\hline 8 & $2.10-2.19(1 \mathrm{H}, \mathrm{m})$ & $2.09(\mathrm{~m})$ \\
\hline \multirow[t]{2}{*}{11} & $2.14(1 \mathrm{H}, \mathrm{dd}, 9.4,3.6)$ & 2.17 (1H, ddd, 13.0, 8.8, 3.2) \\
\hline & $1.83(1 \mathrm{H}, \mathrm{m})$ & $1.83(1 \mathrm{H}, \mathrm{ddd}, 13.0,9.6,4.8)$ \\
\hline \multirow[t]{2}{*}{12} & $2.02(1 \mathrm{H}, \mathrm{dd}, 9.1,3.6)$ & $1.99(1 \mathrm{H}, \mathrm{ddd}, 12.8,8.8,4.8)$ \\
\hline & $1.98(1 \mathrm{H}, \mathrm{dd}, 9.1,4.3)$ & $1.92(1 \mathrm{H}, \mathrm{m})$ \\
\hline \multirow[t]{2}{*}{14} & $2.43(1 \mathrm{H}, \mathrm{dt}, 11.9,9.8)$ & $2.43(1 \mathrm{H}, \mathrm{ddd}, 12.5,9.6,2.4)$ \\
\hline & $1.92(1 \mathrm{H}, \mathrm{ddd}, 11.9,7.3,2.7)$ & 1.94 (1H, ddd, 12.5, 7.2, 3.2) \\
\hline \multirow[t]{2}{*}{15} & $4.11(1 \mathrm{H}, \mathrm{ddd}, 9.8,8.7,2.7) / 4.04(1 \mathrm{H}, \mathrm{td}, 8.5,3.9)$ & $4.13(1 \mathrm{H}, \mathrm{ddd}, 9.6,8.8,3.2) / 4.06(1 \mathrm{H}, \mathrm{m})$ \\
\hline & $3.79(1 \mathrm{H}, \mathrm{td}, 8.7,7.3) / 3.97(1 \mathrm{H}, \mathrm{td}, 8.5,7.0)$ & $3.77(1 \mathrm{H}, \mathrm{ddd}, 8.8,7.2,2.4)) / 4.00(1 \mathrm{H}, \mathrm{m})$ \\
\hline 16 & $4.81(1 \mathrm{H}, \mathrm{s}) / 5.33(1 \mathrm{H}, \mathrm{s})$ & $4.78(1 \mathrm{H}, \mathrm{s}) / 5.37(1 \mathrm{H}, \mathrm{s})$ \\
\hline 17 & $0.95(3 \mathrm{H}, \mathrm{d}, 6.4) / 0.96(3 \mathrm{H}, \mathrm{d}, 6.4)$ & $0.93(3 \mathrm{H}, \mathrm{d}, 6.4)$ \\
\hline 18 & $1.08(3 \mathrm{H}, \mathrm{s}) / 1.07(3 \mathrm{H}, \mathrm{s})$ & $0.91(3 \mathrm{H}, \mathrm{s}) / 0.89(3 \mathrm{H}, \mathrm{s})$ \\
\hline 19 & $1.16(3 \mathrm{H}, \mathrm{s}) / 1.15(3 \mathrm{H}, \mathrm{s})$ & $1.14(3 \mathrm{H}, \mathrm{s}) / 1.18(3 \mathrm{H}, \mathrm{s})$ \\
\hline 20 & $0.88(3 \mathrm{H}, \mathrm{s}) / 0.87(3 \mathrm{H}, \mathrm{s})$ & $0.81(3 \mathrm{H}, \mathrm{s}) / 0.86(3 \mathrm{H}, \mathrm{s})$ \\
\hline $16-\mathrm{OH}$ & & $3.18(1 \mathrm{H}, \mathrm{br} \mathrm{s})^{* 2}$ \\
\hline
\end{tabular}

Table $2{ }^{1}$ H-NMR data.

${ }^{* 1}$ a: leucasperol $\mathrm{A}$; b: leucasperol B; ${ }^{* 2}$ disappeared on treatment with $\mathrm{D}_{2} \mathrm{O}$; a pair of signals from tautomers is shown as "a/b" 
Table $3{ }^{13}$ C-NMR data.

\begin{tabular}{|c|c|c|c|}
\hline \multirow[t]{2}{*}{ Position } & $a / b^{*}$ & $1 / 1 a$ & $1 / 1 a$ \\
\hline & $\delta_{\mathrm{C}}\left(\mathrm{CDCl}_{3}\right)$ & $\delta_{\mathrm{C}}\left(\mathrm{CDCl}_{3}\right)$ & DEPT \\
\hline 1 & 29.9/28.7 & $30.4 / 30.3$ & $\mathrm{CH}_{2}$ \\
\hline 2 & $26.5 / 26.5$ & $17.2 / 17.3$ & $\mathrm{CH}_{2}$ \\
\hline 3 & $78.2 / 78.4$ & $41.5 / 41.5$ & $\mathrm{CH}_{2}$ \\
\hline 4 & $37.4 / 37.4$ & $31.2 / 30.9$ & C \\
\hline 5 & $58.5 / 58.1$ & $58.2 / 57.6$ & $\mathrm{CH}$ \\
\hline 6 & $210.3 / 210.6$ & $210.5 / 210.6$ & C \\
\hline 7 & $48.7 / 48.9$ & $47.6 / 47.8$ & $\mathrm{CH}_{2}$ \\
\hline 8 & $38.6 / 37.8$ & $37.4 / 36.6$ & $\mathrm{CH}$ \\
\hline 9 & $92.7 / 93.0$ & $91.9 / 91.8$ & C \\
\hline 10 & $47.3 / 47.5$ & $46.4 / 46.8$ & C \\
\hline 11 & $29.0 / 31.2$ & $28.0 / 27.6$ & $\mathrm{CH}_{2}$ \\
\hline 12 & $36.6 / 37.2$ & $35.4 / 35.4$ & $\mathrm{CH}_{2}$ \\
\hline 13 & $91.3 / 92.5$ & $90.3 / 91.7$ & C \\
\hline 14 & $35.5 / 31.1$ & $34.6 / 35.9$ & $\mathrm{CH}_{2}$ \\
\hline 15 & $64.8 / 66.3$ & $64.0 / 65.5$ & $\mathrm{CH}_{2}$ \\
\hline 16 & 99.0/101.6 & $98.1 / 100.6$ & $\mathrm{CH}$ \\
\hline 17 & $16.9 / 17.6$ & $16.0 / 16.7$ & $\mathrm{CH}_{3}$ \\
\hline 18 & $27.7 / 27.6$ & $31.7 / 31.6$ & $\mathrm{CH}_{3}$ \\
\hline 19 & $14.9 / 15.0$ & $20.8 / 21.7$ & $\mathrm{CH}_{3}$ \\
\hline 20 & $20.0 / 20.2$ & $19.0 / 19.2$ & $\mathrm{CH}_{3}$ \\
\hline
\end{tabular}

* a: leucasperol A; b: leucasperol B; a pair of signals from tautomers is shown as "a/b"

1a was $\mathrm{C}_{20} \mathrm{H}_{32} \mathrm{O}_{4}$, suggesting a dehydroxylate of leucasperols $\mathrm{A}$ and $\mathrm{B}\left(\mathrm{C}_{20} \mathrm{H}_{32} \mathrm{O}_{5}\right)$. These data indicated that compound $1 / 1 \mathrm{a}$ has a methylene group at the 3-position ( Fig. 2). This structure was supported by the similar chemical shifts at C-3 $\left(\delta_{\mathrm{C}} 44.1 /\right.$ 44.1) of leucasperols $A$ and $B$ analogs bearing a hydroxyl group at C-6 and a methylene group at C-3 instead of a carbonyl group and a hydroxyl group, respectively [15]. The complete structures of $\mathbf{1} / \mathbf{1}$ a were determined by an analysis of the heteronuclear multiple bond correlation (HMBC) and correlation spectroscopy (COSY) spectra, as shown in $\bullet$ Fig. 3. In the nuclear Overhauser effect spectroscopy (NOESY) spectrum of compound 1 ( Fig. 4A), correlations were observed between $\mathrm{H}-2$ and $\mathrm{H}-20$, $\mathrm{H}-11 \beta$ and $\mathrm{H}-20, \mathrm{H}-8$ and $\mathrm{H}-11 \alpha, \mathrm{H}-5$ and $\mathrm{H}-18$. In differential NOE experiments ( $\odot$ Fig. 4B), irradiation of the $\mathrm{H}-16$ proton resulted in NOE effects on $\mathrm{H}-1$ (9.7\%) and $\mathrm{H}-12$ (3.3\%). These data indicated that the relative configuration of compound $\mathbf{1}$ is as shown in $\odot$ Fig. 4. This configuration was supported by some reports on isolation of constituents having the same configuration from congener plants [16-19]. Since a compound bearing a hemiacetal group generally shows an equilibrium between two stereoisomers, the epimeric ratio varies depending on the solvent and on the temperature [20]. Compounds 1/1a showed an equilibrium, and the epimeric ratios of 1 and 1 a were changed by the solvents used for NMR [1/1a; $4: 1$ mixture $\left(\mathrm{CDCl}_{3}\right), 5: 4$ mixture (DMSO- $d_{6}$ ); Fig. $3 \mathrm{~S}$, Table $1 \mathrm{~S}$, Supporting Information]. Consequently, the structures of 1 and 1 a were $\left(2 R^{*}, 2^{\prime \prime} R^{*}, 3 S^{*}, 4 \mathrm{a}^{\prime \prime}\right.$ $\left.S^{*}, 5^{\prime} R^{*}, 8 a^{\prime \prime} S^{*}\right)$-2-hydroxy-2",5",5",8a"-tetramethyldodecahydro$2 H, 4^{\prime \prime} H$-dispiro[furan-3,2'-furan-5',1"-naphthalen]-4"-one and $\left(2 S^{*}, 2^{\prime \prime} R^{*}, 3 S^{*}, 4 a^{\prime \prime} S^{*}, 5^{\prime} R^{*}, 8 a^{\prime \prime} S^{*}\right)-2$-hydroxy-2",5",5",8a"-tetramethyldodecahydro-2H,4"H-dispiro[furan-3,2'-furan-5',1"naphthalen]-4"-one, respectively. We propose the trivial names chastol and epichastol for compounds $\mathbf{1}$ and $\mathbf{1 a}$.
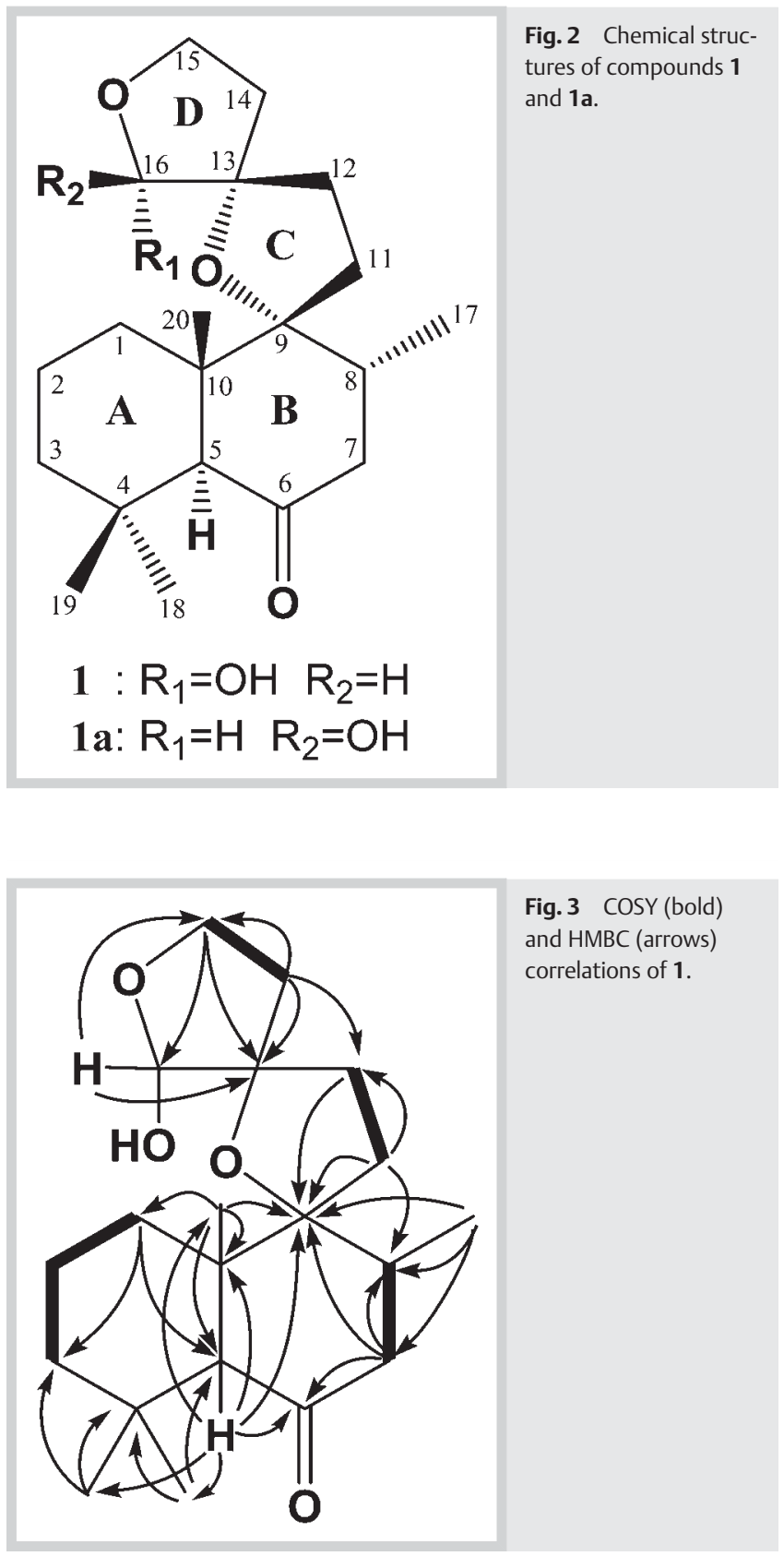

\section{Discussion}

$\nabla$

In the present study, the botanical origins of 2 ACF and 5 SCTF crude drug products were confirmed by DNA sequence analysis, and then extracts of each crude drug were analyzed by LC-MS. Subsequent differential analysis of ACF and SCTF by comparison of their chromatographic patterns revealed 7 peaks of $V$. agnuscastus that could distinguish it from both $V$. rotundifolia and $V$. trifolia. The calculated chemical formulas based on the accurate mass and MS fragmentation pattern of these peaks were collated with the phytochemical metabolite database, and 1 diterpene $\left(\mathrm{C}_{20} \mathrm{H}_{31} \mathrm{O}_{4}\right.$ for $\left.[\mathrm{M}-\mathrm{H}]^{-}\right), 5$ iridoids $\left[\mathrm{C}_{25} \mathrm{H}_{29} \mathrm{O}_{12}\right.$ (2 peaks), $\mathrm{C}_{25} \mathrm{H}_{29} \mathrm{O}_{13}, \mathrm{C}_{26} \mathrm{H}_{31} \mathrm{O}_{14}$ and $\mathrm{C}_{34} \mathrm{H}_{35} \mathrm{O}_{15}$ for $\left.[\mathrm{M}-\mathrm{H}]^{-}\right]$and 1 unknown compound $\left(\mathrm{C}_{13} \mathrm{H}_{23} \mathrm{O}_{8}\right.$ for $\left.[\mathrm{M}-\mathrm{H}]^{-}\right)$were predicted as the marker candidates. We isolated the diterpene candidate to identify new compounds, chastol (1) and epichastol (1a) as the first putative 


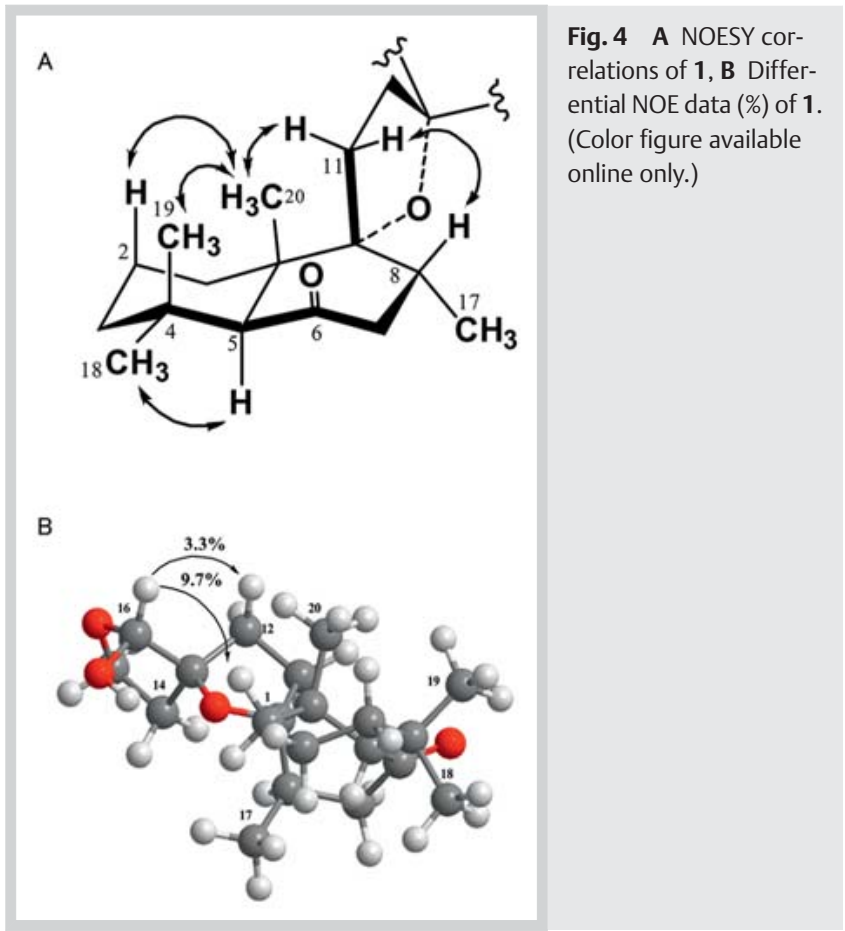

marker compounds. Further study for the other candidates is ongoing.

Compounds $\mathbf{1}$ and $\mathbf{1 a}$ are labdane-type diterpenes having two spirotetrahydrofuran rings, a carbonyl group at the 6-position and a methylene group at the 7-position. There have been no reports on the isolation of compounds bearing this structure, except for leucasperols A and B from Leucas aspera L. (Lamiaceae) [14]. The genus Vitex was earlier classified in the Verbenaceae family, based on morphological features (e.g., the modified Engler and Cronquist system), but later reclassified in the Lamiaceae family according to the APG system, which is based on DNA sequences [21]. Thus, the structural similarity of $\mathbf{1}$ and $\mathbf{1 a}$ to leucasperols $\mathrm{A}$ and $\mathrm{B}$ bearing both a carbonyl group at the 6-position and a methylene group at the 7-position supports this reclassification from a chemotaxonomical viewpoint.

The distribution of standardized products in the market requires the correct recognition of the quality of the raw materials based on the composition and the content of chemical constituents, as well as the accurate botanical origin and the GMP-guiding manufacturing process. Though casticin, agnuside and aucubin are used as marker compounds for the standardization of ACF in EP8.0, some reports have shown [11-13] that they can be found in other Vitex species, and these compounds were indeed detected in SCTF crude drugs in our study (data not shown). Conversely, a much larger amount of compounds $\mathbf{1}$ and $\mathbf{1 a}$ was detected from ACF than from SCTF, and the detection of these puta- tive markers was also confirmed from commercial ACF medicines and health food products ( $\odot$ Table 4, Fig. 4 S, Supporting Information). Therefore, the detection of the characteristic marker compounds for ACF, chastol and epichastol, should help preventing the use of adulterated materials in SCTF products, and would also be a useful means of identifying the origin of raw materials in ACF products.

In conclusion, we identified new diterpenes, chastol and epichastol, as putative marker compounds distinguishing Agnus Castus Fruit from Shrub Chaste Tree Fruit. Since avoiding contamination from closely related species is needed for the quality control of natural pharmaceuticals, this information should be valuable to establish a method for determining the quality of both ACF and SCTF products.

\section{Materials and Methods \\ $\nabla$ \\ Materials}

ACF crude drugs of EP8.0 grade and medicines were purchased from pharmacies in Europe. SCTF of non-JP crude drug standards grade and ACF health food products were purchased from manufacturers in Japan and from internet stores, respectively. Details are shown in $\bullet$ Tables 1 and 4.

\section{General procedure}

Optical rotation was measured with a DIP-370 digital polarimeter (Jasco). IR spectra were recorded on an FT/IR 6100 Fourier transform infrared spectrometer (Jasco). ${ }^{1} \mathrm{H}-,{ }^{13} \mathrm{C}$-, and 2D-NMR spectra were recorded on an ECA-800 or ECA-600 spectrometer (JEOL), and the chemical shifts were referenced to TMS as the internal standard.

\section{DNA sequence analysis}

Total DNA was extracted from $10-50 \mathrm{mg}$ of powdered samples using a Maxwell 16 Tissue DNA Purification Kit (Promega). A partial sequence of the chloroplast mat $K$ gene (1165 bp) was amplified via PCR using AmpDirect Plus PCR buffer (Shimadzu) and EX Taq DNA polymerase (Takara) with specific primers 3F_KIMf (5'CGT ACA GTA CTT TTG TGT TTA CGA G-3') and 1R_KIMr (5'-ACC CAG TCC ATC TGG AAA TCT TGG TTC-3') under the following conditions: $94^{\circ} \mathrm{C}$ for $2 \mathrm{~min}, 30$ cycles of $94^{\circ} \mathrm{C}$ for $10 \mathrm{sec}, 55^{\circ} \mathrm{C}$ for $30 \mathrm{sec}$, and $72^{\circ} \mathrm{C}$ for $1 \mathrm{~min}$, then $72^{\circ} \mathrm{C}$ for $4 \mathrm{~min}$. Fragments of the nuclear FLORICAULA/LEAFY (FLO/LFY) second intron were also amplified with the specific primer set Vitex-LFint2F1 (5'-AAT GCC GCG AGT TCT TGA TA-3') and Vitex-LFint2R1 (5'-GCA TAC CTG AAC ACT TGG TTT G-3') for full-length fragments and the set Vitex-LFint5F (5'-CTC TTT TGG TGT TGG GGG TAG-3') and Vitex-LFint5R (5'-GTG AAA CAC CCA TGA ATT GTT AG-3') for a 377 bp fragment. The resulting PCR products were detected by an MCE-202 MultiNA microchip electrophoresis system (Shimadzu) and purified using a MinElute PCR purification kit (QIAGEN). The

$\begin{array}{llllll}\begin{array}{l}\text { Sample } \\ \text { ID }\end{array} & \text { Product } & \text { Distributor country } & \text { Form } & \text { Contents } & \text { Lot Nos. } \\ \text { ACF-11 } & \text { Medicine } & \text { Germany } & \text { tablet } & \text { dry extract } 5 \mathrm{mg} & 0000049883 \\ \text { ACF-12 } & \text { Medicine } & \text { Germany } & \text { capsule } & \text { dry extract } 5 \mathrm{mg} & 93323 \\ \text { ACF-13 } & \text { Medicine } & \text { Switzerland } & \text { tablet } & \text { dry extract 20 mg } & 100056 \\ \text { ACF-21 } & \text { Health food product } & \text { USA } & \text { capsule } & \text { dry extract 225 mg } & 109344 \\ \text { ACF-22 } & \text { Health food product } & \text { USA } & \text { capsule } & \text { powdered fruit 400 mg } & 110723\end{array}$

Table 4 ACF medicines and health food products containing chasteberry. 
377 bp fragment of the FLO/LFY second intron from SCTF1 was subcloned into the PCR2.1-TOPO vector (Invitrogen) for sequencing. Sequencing was performed using a BigDye Terminator v3.1 Cycle Sequencing Kit (Applied Biosystems), and each nucleotide sequence was determined by an ABI PRISM 3130 genetic analyzer (Applied Biosystems).

\section{Liquid chromatography-tandem mass spectrometry analysis}

An aliquot (200 mg) of each powdered crude drug sample was extracted with $10 \mathrm{~mL}$ of $75 \% \mathrm{MeOH}$ by sonication for $3 \mathrm{~h}$ at room temperature and centrifuged at $12000 \mathrm{~g}$ for $10 \mathrm{~min}$ to obtain a supernatant. The supernatant was diluted 20 -fold to a final concentration of $1 \mathrm{mg} / \mathrm{mL}$ and filtered through a $0.45 \mu \mathrm{m}$ UltrafreeMC centrifugal filter unit (Millipore) before LC/MS. A $10 \mu \mathrm{L}$ aliquot of the filtrate was injected and LC/MS/MS analyses were carried out using a Prominence UFLC (Shimadzu) equipped with a Hypersil GOLD column $(2.1 \times 100 \mathrm{~mm}, 1.9 \mu \mathrm{m}$; Thermo Scientific) and coupled to an LTQ Orbitrap XL mass spectrometer (Thermo Scientific). The mobile phase, consisted of water containing $0.1 \%$ formic acid (solvent $\mathrm{A}$ ) and acetonitrile containing $0.1 \%$ formic acid (solvent B), was delivered at a flow rate of $0.2 \mathrm{~mL} / \mathrm{min}$. The gradient started at $20 \%$ solvent B and increased linearly to $90 \%$ in $35 \mathrm{~min}$, then to $100 \%$ in $5 \mathrm{~min}$. The column temperature was $40^{\circ} \mathrm{C}$. The mass spectra were obtained in electrospray ionization-negative mode using the following parameters: needle voltage: $3000 \mathrm{~V}$; capillary temperature: $300^{\circ} \mathrm{C}$; target mass resolution: $30000 ; \mathrm{m} / \mathrm{z}$ range: $100-2000$. The most intense ions in the full-scan mass spectrum were isolated with a 3.5 Da window and fragmented by collision-induced dissociation with a collision energy of $35 \mathrm{~V}$. Mass calibration was accomplished by using polythyrosine as an external standard according to the manufacturer's instructions.

\section{Differential liquid chromatography-mass spectrometry data analysis}

Differential expression analysis for LC/MS-based metabolomics was performed using the SIEVE 2.0 software (Thermo Scientific) with the Base Peak Framing algorithm for chromatographic alignment, framing, and differential analyses. MS chromatograms were unaligned by setting the alignment bypass to "true". For the frame creation, $m / z$ width was set to $10 \mathrm{ppm}$ ( $\pm 5 \mathrm{ppm}$ ), retention time width to $0.3 \mathrm{~min}$, and peak intensity threshold to 275000. Two sample differential analyses were carried out between ACF and SCTF to obtain the ratio of peak intensity and the $\mathrm{p}$ value, indicating the level of statistical significance. Chemical formulas of the candidate compounds were extracted from the accurate mass with a tolerance $<4$ ppm via the elemental composition tool in Xcalibur (Thermo Scientific).

Liquid chromatography-mass spectrometry for isolation ACF, SCTF, and health food products containing chasteberry extract were extracted with $\mathrm{CHCl}_{3}$ to a final concentration of $2 \mathrm{mg}$ / $\mathrm{mL}$ and filtered through filter paper to remove muddy substances. After filtration through a $0.45 \mu \mathrm{m}$ Ultrafree-MC centrifugal filter unit, $10 \mu \mathrm{L}$ of the filtrate was injected and LC-MS/MS carried out using a Prominence UFLC, equipped with an Inertsil ODS- 4 column $(4.6 \times 250 \mathrm{~mm}, 5 \mu \mathrm{m}$; GL Sciences $)$, coupled to an LTQ Orbitrap XL mass spectometer. The mobile phase, consisted of water (solvent A) and $\mathrm{MeOH}$ (solvent $\mathrm{B}$ ), was delivered at a flow rate of $1.0 \mathrm{~mL} / \mathrm{min}$. The gradient started at $50 \%$ solvent $B$ for $10 \mathrm{~min}$ and increased linearly to $80 \%$ in $5 \mathrm{~min}$, then to $100 \%$ in $15 \mathrm{~min}$. The column temperature was $40^{\circ} \mathrm{C}$.

\section{Extraction and isolation}

The content of capsules ( $180 \mathrm{~g}$ or 580 capsules) of a commercial health food product derived from ACF extract (ACF-21) was extracted ultrasonically with $\mathrm{CHCl}_{3}(7.2 \mathrm{~L})$ for $3 \mathrm{~h}$. After filtering the extract, it was evaporated under reduced pressure to give a crude dry extract $(3.41 \mathrm{~g})$, which was dissolved in $\mathrm{CHCl}_{3}(8 \mathrm{~mL})$ and applied to silica gel $(10 \mathrm{~g})$. This silica gel was added to the top of a silica gel column for chromatography (Ø $4.4 \times 21 \mathrm{~cm}$ ), eluted with $n$-hexane-EtOAc $(1: 0 \rightarrow 1: 4)$ to give six fractions [ $\mathrm{fr}$. A-1, $n$-hexane $(600 \mathrm{~mL})$ eluate; fr. A-2, $n$-hexane: EtOAc $=4: 1$ $(600 \mathrm{~mL})$ eluate; fr. A-3, $n$-hexane $:$ EtOAc $=7: 3(600 \mathrm{~mL})$ eluate; fr. A-4, $150 \mathrm{mg}, n$-hexane $:$ EtOAc $=3: 2(600 \mathrm{~mL})$ eluate; fr. A-5, $n$-hexane: EtOAC $=1: 1 \quad(600 \mathrm{~mL})$ eluate; fr. A-6, $n$-hexane: EtOAc $=1: 4(600 \mathrm{~mL})$ eluate $].$ Fr. A-4 $(150 \mathrm{mg})$ was dissolved in $\mathrm{CHCl}_{3}(1 \mathrm{~mL})$ and chromatographed on a silica gel column ( $2 \times 25 \mathrm{~cm})$ with $\mathrm{CHCl}_{3}: \mathrm{MeOH}(1: 0 \rightarrow 1: 1)$ to give six fractions [fr. $\mathrm{B}-1, \mathrm{CHCl}_{3}$ eluate $(100 \mathrm{~mL})$; fr. $\mathrm{B}-2,10 \mathrm{mg}, \mathrm{CHCl}_{3}: \mathrm{MeOH}=99: 1$ (100 mL) eluate; fr. B-3, $40 \mathrm{mg}, \mathrm{CHCl}_{3}: \mathrm{MeOH}=19: 1(100 \mathrm{~mL})$ eluate; fr. $\mathrm{B}-4,30 \mathrm{mg}, \mathrm{CHCl}_{3}: \mathrm{MeOH}=9: 1(100 \mathrm{~mL})$ eluate; fr. B-5, $10 \mathrm{mg}, \mathrm{CHCl}_{3}: \mathrm{MeOH}=4: 1 \quad(100 \mathrm{~mL})$ eluate; fr. B-6, $\mathrm{CHCl}_{3}$ : $\mathrm{MeOH}=1: 1(100 \mathrm{~mL})$ eluate]. Fr. B-4 (30 mg) was repeatedly separated by preparative TLC ( $n$-hexane: $\mathrm{EtOAc}, \mathrm{CHCl}_{3}: \mathrm{MeOH}$ ) to obtain compound $\mathbf{1 / 1}$ a [1.7 mg, $\mathrm{R}_{f} 0.50$ (yellow spot; $n$-hexane: EtOAc $1: 1 ; p$-anisaldehyde-sulfuric acid)].

Chastol/epichastol (1/1a): white powder; $[\alpha]_{\mathrm{D}}^{25}+16.7$ (c 0.3 , $\left.\mathrm{CHCl}_{3}\right)$, + 3.3 (c 0.3, DMSO); IR $\left(\mathrm{CHCl}_{3}\right) \mathrm{v}_{\max } 3749,2917,1703$, 1540, 1124, $940 \mathrm{~cm}^{-1 ; 1} \mathrm{H}-\mathrm{NMR}$, see $\odot$ Table $2 ;{ }^{13} \mathrm{C}-\mathrm{NMR}$, see $\odot \mathrm{Ta}$ ble 3; HRTOFMS m/z $335.2223[\mathrm{M}-\mathrm{H}]^{-}$(calcd. for $\mathrm{C}_{20} \mathrm{H}_{31} \mathrm{O}_{4}$, 335.2222).

\section{Supporting information}

${ }^{1} \mathrm{H}-\mathrm{NMR}$ and ${ }^{13} \mathrm{C}$-NMR spectra of compound $\mathbf{1}$ are available as Supporting Information.

\section{Conflict of Interest}

$\nabla$

All authors declare no conflict of interest associated with this manuscript.

\section{Affiliations}

1 Division of Pharmacognosy, Phytochemistry and Narcotics, National Institute of Health Sciences, Tokyo, Japan

2 College of bioresource Sciences, Nihon University, Kanagawa, Japan

${ }^{3}$ MS-Solutions Co. Ltd., Tokyo, Japan

${ }^{4}$ School of Pharmaceutical Sciences, International University of Health and Welfare, Tochigi, Japan

${ }^{5}$ Medicinal Plants Eco-frontier Center, School of Pharmacy, Kumamoto University, Kumamoto, Japan

${ }^{6}$ Research Center for Medicinal Plant Resources, National Institute of Biomedical Innovation, Ibaraki, Japan

\section{References}

1 Roemheld-Hamm B. Chasteberry. Am Fam Physician 2005; 72: 821-824

2 Belic I, Bergant-Dolar J, Morton RA. Constituents of Vitex agnus castus seeds. Part I. Casticin. J Chem Soc 1961; 2523-2525

3 Hirobe C, Qiao ZS, Takeya K, Itokawa H. Cytotoxic flavonoids from Vitex agnus-castus. Phytochemistry 1997; 46: 521-524

4 Kuruuzum-Uz A, Ströch K, Demirezer LO, Zeeck A. Glucosides from Vitex agnus-castus. Phytochemistry 2003; 63: 959-964

5 Ono M, Yamasaki T, Konoshita M, Ikeda T, Okawa M, Kinjo J, Yoshimitsu $H$, Nohara $T$. Five new diterpenes, viteagnusins A-E, from the fruit of Vitex agnus-castus. Chem Pharm Bull 2008; 56: 1621-1624 
6 Hoberg E, Orjala J, Meier B, Sticher O. Diterpenoids from the fruits of Vitex agnus-castus. Phytochemistry 1999; 52: 1555-1558

7 The European Directorate for the Quality of Medicines. The European Pharmacopoeia, 8th edition. Strasbourg: Council of Europe; 2014: $1137-1138$

8 United States Pharmacopeial Convention. The United States Pharmacopeia 34 - The National Formulary 29. Rockville: USP; 2011: 1105-1107

9 van Die MD, Burger HG, Teede HJ, Bone KM. Vitex agnus-castus extracts for female reproductive disorders: a systematic review of clinical trials. Planta Med 2013; 79: 562-575

10 Wuttke W, Jarry H, Christoffel V, Spengler B, Seidlová-Wuttke D. Chaste tree (Vitex agnus-castus) - pharmacology and clinical indications. Phytomedicine 2003; 10: 348-357

$11 \mathrm{Hu}$ Y, Xin HL, Zhang QY, Zheng HC, Rahman K, Qin LP. Anti-nociceptive and anti-hyperprolactinemia activities of Fructus Viticis and its effective fractions and chemical constituents. Phytomedicine 2007; 14: 668-674

12 Ono M, Ito Y, Kubo S, Nohara T. Two new iridoids from Viticis trifoliate fructus (fruit of Vitex rotundifolia L.). Chem Pharm Bull 1997; 45: 1094-1096

13 Hänsel R, Leuckert CH, Rimpler H, Schaaf KD. Chemotaxomische Untersuchungen in der Gattung Vitex L. Phytochemistry 1965; 4: 19-27
14 Sadhu SK, Okuyama E, Fujimoto H, Ishibashi M. Diterpenes from Leucas aspera inhibiting prostaglandin-induced contractions. J Nat Prod 2006; 69: 988-994

15 Wu H, Li J, Fronczek FR, Ferreira D, Burandt CL jr., Setola V, Roth BL, Zjawiony JK. Labdane diterpenoids from Leonotis leonurus. Phytochemistry 2013; 91: 229-235

16 Ono M, Yamasaki T, Konoshita M, Ikeda T, Okawa M, Kinjo J, Yoshimitsu $H$, Nohara $T$. Five new diterpenoids, viteagnusins A-E, from the fruit of Vitex agnus-castus. Chem Pharm Bull 2008; 56: 1621-1624

17 Franks F, Lillford PJ, Robinson G. Isomeric equilibria of monosaccharides in solution. Influence of solvent and temperature. J Chem Soc Faraday Trans 1989; 85: 2417-2426

18 Ono M, Nagasawa Y, Ikeda T, Tsuchinashi R, Okawa M, Kinjo J, Yoshimitsu $H$, Nohara T. Three new diterpenoids from the fruit of Vitex agnus-castus. Chem Pharm Bull 2009; 57: 1132-1135

19 Ono M, Eguchi K, Konoshita M, Furusawa C, Sakamoto J, Yasuda S, Ikeda T, Okawa M, Kinjo J, Yoshimitsu H, Nohara T. A new diterpenoid glucoside and two new diterpenoids from the fruit of Vitex agnus-castus. Chem Pharm Bull 2011; 59: 392-396

20 Pal M, Li SH, Tewari SK, Sun HD. Diterpenoid compounds from Vitex agnus-castus. Chem Nat Compd 2013; 49: 635-638

$21 \mathrm{Oba} \mathrm{H}$. Syllabus of the vascular plants of Japan, 3rdedition. Tokyo: Aboc; 2011: 206-212 